Accesed on: http://jkb.ub.ac.id/index.php/jkb/article/view/2714

Jurnal Kedokteran Brawijaya Vol. 31, No. 2, Agustus 2020, pp. 111-115

Article History: Received 8 Februari 2020, Accepted 11 Agustus 2020

Research Article

Physical Activity Correlates to Body Mass Index among Medical Students

\title{
Aktivitas Fisik Berhubungan dengan Indeks Massa Tubuh pada Mahasiswa Kedokteran
}

\author{
Nura Eky $V^{1}$, Hadi Sarosa ${ }^{1}$, Fadli Rizal $M^{2}$, Minidian Fasitasari ${ }^{3}$ \\ ${ }^{1}$ Department of Physiology Faculty of Medicine Universitas Islam Sultan Agung Semarang \\ ${ }^{2}$ Department of Pathology Anatomy Faculty of Medicine Universitas Islam Sultan Agung Semarang \\ ${ }^{3}$ Department of Nutrition Faculty of Medicine Universitas Islam Sultan Agung Semarang
}

\begin{abstract}
Physical activity (PA) has a positive effect on preventing risk on cardiovascular and metabolic syndrome, including obesity. Learning behavior that tends to be sedentary causes medical students to tend to be physically inactive. This present study aimed to associate the physical activity (PA) level with blood pressure, body mass index, and non-fasting blood glucose level (NFBG) among medical students. This cross-sectional study was conducted from February to March in 2019 on the first-year medical students at Sultan Agung Islamic University (UNISSULA). A total of 167 medical students (64.7\% female and 35.3\% male) were enrolled in this study. The international physical activity questionnaire (IPAQ)-short form was used to measure the PA level. The activity level was classified into low, moderate, and high. Blood pressure and glucose level were measured using a digital sphygmomanometer and NFBG dipstick. The association between PA level and Body Mass Index (BMI), Blood Pressure (BP), and NFBG level were analyzed using Spearman's correlation test. Chi square test was done to analyse the difference of $P A$ level between male and female groups. The majority of the respondents had a low $P A$ level (64.7\%). A positive association was shown between PA level and BMI ( $p<0.05, r=0.192)$. Female medical students tend to be physically inactive than males (OR 2.004, 95\% Cl (1.038-3.8690)). Female students need to be encouraged to do more physical activity. The university's policies that promote physical outdoor activity need to be suggested.
\end{abstract}

Keywords: Blood pressure, BMI, IPAQ, non-fasting blood glucose level

\begin{abstract}
ABSTRAK
Aktivitas fisik memilki dampak positif pada pengendalian risiko kardiovaskular dan sindroma metabolik, termasuk obesitas. Perilaku belajar yang cenderung sedenter menyebabkan mahasiswa kedokteran cenderung inaktif secara fisik. Penelitian ini bertujuan untuk menghubungkan tingkat aktivitas fisik dengan tekanan darah, index massa tubuh (IMT), dan kadar glukosa darah sewaktu (GDS) pada mahasiswa kedokteran. Studi cross-sectional ini dilakukan selama bulan Februari hingga Maret 2019 pada mahasiswa kedokteran tahun pertama di fakultas kedokteran Universitas Islam Sultan Agung (UNISSULA). Sejumlah 167 mahasiswa (64.7\% wanita dan 35.5\% laki-laki) mengikuti studi ini. International physical activity questionnaire (IPAQ) short form digunakan untuk mengukur tingkat aktivitas fisik. Tingkat aktivitas fisik selanjutnya dikelompokan menjadi rendah, sedang, dan tinggi. Tekanan darah dan GDS diukur menggunakan spigmomanometer digital dan dipstik GDS. Hubungan antara level aktivitas fisik dengan IMT, tekanan darah, dan GDS dianalisis menggunakan uji korelasi Spearman's. Chi square test dilakukan untuk menganalisis perbedaan tingkat aktivitas fisik diantara kelompok laki-laki dan wanita. Mayoritas responden memiliki tingkat aktivitas fisik rendah (64.7\%). Korelasi positif ditunjukan antara tingkat aktivitas fisik dan IMT $(p<0.05, r=0.192)$. Mahasiswa wanita cenderung lebih inaktif dibanding laki-laki (OR 2.004, 95\% Cl (1.038-3.8690)). Mahasiswa wanita perlu dimotivasi untuk melakukan aktivitas fisik lebih banyak yang didukung kebijakan dari universitas untuk mempromosikan aktivitas fisik luar ruangan.
\end{abstract}

Kata Kunci: GDS, IMT, IPAQ, tekanan darah

Correspondence: Nura Eky V. Department of Physiology Faculty of Medicine Universitas Islam Sultan Agung Semarang, Jalan Kaligawe KM. 04, Semarang Central Java Tel. (024)6583584Email:nuraeky@unissula.ac.id

DOI: http://dx.doi.org/10.21776/ub.jkb.2020.031.02.8 


\section{INTRODUCTION}

A low level of physical activity poses health problems that threaten future generations. In 2010, WHO reported that $23 \%$ of the adult population over 18 years old and $81 \%$ of the adolescents around 11-17 years old worldwide had inadequate physical activity (PA). Physical inactivity contributes to $3 \%$ of morbidity in developing countries and more than $20 \%$ incident of cardiovascular disease, $10 \%$ incident of stroke, and 3.2 million mortality every year $(1,2)$. PA is defined as all body movements resulted from skeletal muscle contraction which consumes energy, and exercises are part of physical activity $(2,3)$. Global Recommendations on Physical Activity for Health from WHO suggest an aerobic PA with moderate intensity for at least 150 minutes in a week for adult and moderate-vigorous PA for at least 60 minutes a day for children and adolescents (4).

Data show a shift in the tendency of degenerative diseases at a younger age. Several studies revealed an association between PA and hypertension, obesity, and diabetes. The studies presented a protective association of PA in reducing the risk of cardiovascular and metabolic diseases (5-9). Lately, the tendency of increasing blood pressure in children and adolescents is not surprising. Increasing blood pressure in children and adolescents will multiply the risk of hypertension in adulthood $(6,10)$. Moreover, epidemiological data showed that reducing physical activity along with a sedentary lifestyle correlates with the risk of obesity and type 2 diabetes mellitus (T2DM) in children and adolescents $(11,12)$. Previous study conducted on senior high school students in Pekanbaru, Indonesia showed that the majority of the students had low PA levels. The study also demonstrated a positive association between body mass index (BMI) and blood pressure (13).

Medical students should have a better understanding of healthy living behaviors, but, on the other hand, learning activities like reading or sitting in front of computer and wealth social status foster sedentary behavior. Research in Thailand found that medical students tend to be physically inactive due to their study-related activities. The study showed that more than half of the medical students were physically inactive (2). This study aimed to explore the association between PA level and blood pressure, blood glucose level, and body mass index among medical students in Indonesia.

\section{METHOD}

\section{Design}

This study was an observational study with a crosssectional approach conducted from February to March 2019 at the Physiology Laboratory, Faculty of Medicine, UNISSULA. A total of 168 first-year medical students was included in this study. One female participant was excluded due to medical history related to cardiovascular abnormality (ventricular septal defect). All participants agreed to participate following all contained in the informed consent sheet before the study began.

\section{Measurement}

The international physical activity questionnaire (IPAQ)short form was used to measure the PA level. All participants were asked to complete the questionnaires after reading the instructions. There was no limitation time to fill the questionnaire. The IPAQ data were then tabulated using an easy-to-use spreadsheet to evaluate the IPAQ scoring automatically (14). The data were categorized as low, moderate, and high $(14,15)$.
The blood pressure measurement was performed once using OMRON Automatic Blood Pressure Monitor HEM7130 (OMRON Healthcare manufacturing, Binh Duong Province, Vietnam Co.LTD). The participants rested for at least 10 minutes before the measurement and were not allowed to consume coffee, take an anti-hypertension drug, or smoke before the test.

The non-fasting blood glucose (NFBG) levels were measured once using Nesco Multicheck glucose test strips (Kernel Int'l Corp, Hsinchu, Taiwan). All participants reported no history of diabetes mellitus or symptoms of polyphagia, polydipsia, or polyuria.

Body mass index (BMI) was measured by calculating body weight in kilograms divided by height in meters squared. Body weight was measured once using a weight scale (ZT120, Health Scale). Participants were asked to stand upright on the scale without wearing a belt and carrying any items inside their pockets such as a watch, glasses, coins, and a wallet. Height was measured using a wallmounted stadiometer. Participants were asked to stand bare feet and face straight ahead where shoulder, buttocks, and heels were against the wall (16).

\section{Analysis}

All the data were analyzed descriptively, followed by nonparametric Spearman's correlation in SPSS for windows ver.17 to seek the association between PA level and BMI, $B P$, and NFBG levels. A Chi-Square test was used to analyze the difference of PA level between male and female groups. An Independent sample t-test was completed to analyze the difference of BMI, BP, and NFBG levels between male and female groups.

\section{RESULTS}

Among 167 participants, 59 (35.3\%) were male, and 108 $(64.7 \%)$ were female. Descriptive data of age, BMI, systolic and diastolic pressure, NFBG, and metabolic equivalent of task (MET) score among the participants are shown in Table 1. Based on JNC VII criteria, the proportion of systolic prehypertension (systolic BP: $120-139 \mathrm{mmHg}$ ) and systolic hypertension (systolic BP: $\geq 140 \mathrm{mmHg}$ ) among the participants were $25.7 \%$ and $4.2 \%$, respectively. However, $32.3 \%$ and $4.8 \%$ of the participants had diastolic prehypertension (diastolic BP: $80-89 \mathrm{mmHg}$ ) and diastolic hypertension (diastolic BP: $\geq 90 \mathrm{mmHg}$ ), respectively. Systolic pressure in participants with prehypertension or hypertension was higher in males than females while diastolic pressure in prehypertension or hypertension was predominantly in females than males. The NFBG level of all participants showed normal results $(<200 \mathrm{mg} / \mathrm{dL}$ ). None of the participants had any history of type 2 diabetes mellitus (T2DM) or suspicious symptoms of T2DM.

Table 1. Descriptive analysis of research variables $(n=167)$

\begin{tabular}{lrrrr}
\hline \multicolumn{1}{c}{ Variable } & Minimum & Maximum & Mean & $\begin{array}{c}\text { Standard } \\
\text { deviation } \\
\text { (SD) }\end{array}$ \\
\hline Age (years old) & 16 & 21 & 18.45 & 0.75 \\
BMI (kg/m $\left.{ }^{2}\right)$ & 15.4 & 41.7 & 23.01 & 4.76 \\
$\begin{array}{l}\text { Systolic pressure } \\
\text { (mmHg) }\end{array}$ & 85 & 178 & 114.68 & 13.82 \\
$\begin{array}{l}\text { Diastolic pressure } \\
\text { (mmHg) }\end{array}$ & 56 & 96 & 76.28 & 7.77 \\
$\begin{array}{l}\text { NFBG (mg/dL) } \\
\text { MET score of PA }\end{array}$ & 52 & 189 & 87.71 & 20.44 \\
\hline
\end{tabular}


The MET PA scores were then categorized into low, moderate, and high. The PA level categories of the participants based on gender are shown in Table 2 . The majority of PA levels of participants were low (64.7\%). The data show that both male and female tend to have low PA. Nevertheless, the proportion of inactive female was higher than male. A chi-square analysis showed that there was a significant difference in the proportion of physical activity level between males and females $(p<0.001)$. Females are more likely to have lower level of PA than males (OR=2.004, 95\% Cl (1.038-3.8690).

Table 2. The physical activity level based on gender

\begin{tabular}{llrrr}
\hline & \multicolumn{3}{c}{ Gender } \\
& & Female (\%) & Male (\%) & Total \\
\hline \multirow{2}{*}{ Physical } & Low & $76(70.3 \%)$ & $32(54.3 \%)$ & 108 \\
activity level & Moderate & $25(23.1 \%)$ & $10(16.9 \%)$ & 35 \\
& High & $7(6.6 \%)$ & $17(28.8 \%)$ & 24 \\
\hline Total & $108(100 \%)$ & $59(100 \%)$ & 167 \\
\hline
\end{tabular}

The non-parametric statistic was done using Spearman's correlation to analyse the association between PA level and BMI, SBP, DBP, and NFBG level. No correlation was found between PA level and NFBG level, systolic or diastolic blood pressure. A positive correlation was found between PA level and BMI $(p=0.013)$, however it was a weak correlation ( $r=0.192)$. The figure 1 demonstrated the scatter plot of BMI among the different PA level. It showed that low PA level was dominant in lower BMI score participant. A significant difference between BMI among male and female groups was shown in this study ( $p$ value $=0.004)$. The normal $\mathrm{BMI}$ among females in this study was dominant (59.3\%) followed by pre-obese and obese (22.2\%) and underweight (18.5\%). The normal BMI among males were counted for $50.8 \%$, followed by preobese and obese (37.3\%), and underweight (11.9\%). Thus, the dominant BMI among participants are normal (55.0\%) followed by pre-obese and obese (29.8\%), and underweight (15.2\%). The significant difference of BMI and systolic blood pressure between male and female groups was shown in this study, $p$ value was 0.004 and 0.000 , respectively.

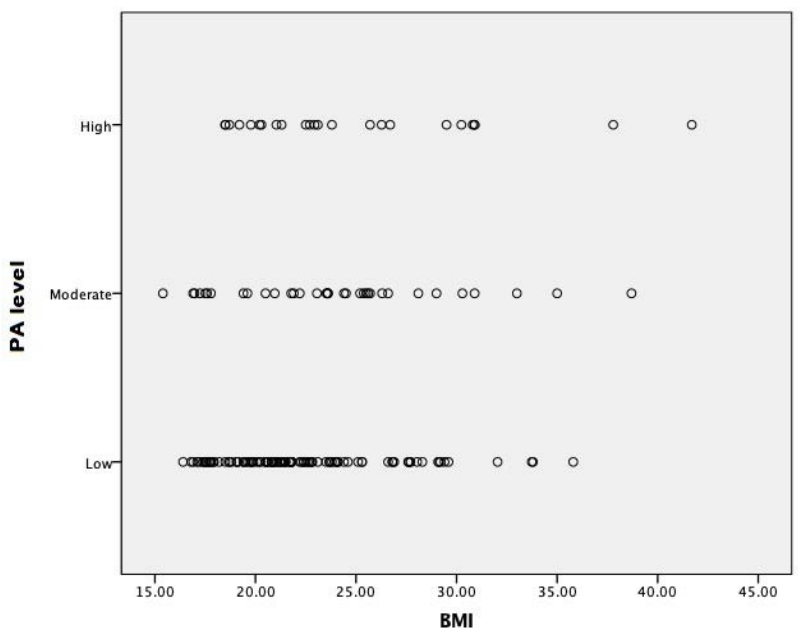

Figure 1. Scatter plot of physical activity level category and BMI

\section{DISCUSSION}

A positive correlation of PA level and BMI was shown in this study but in a weak correlation ( $p=0.013, r=0.192)$. However, the correlation between PA level and BMI remains inconsistent. Other studies among medical students showed no significant relationship between PA and BMI $(17,18)$. In contrast, a study by Keykhaei et al. showed that there was a significant relationship between BMI $(p=.018)$ and PA score in normal BMI participants compared to those with obesity. However, the PA score had no significant difference in underweight and overweight participants (19). Unique to our finding is that participants with lower BMI are likely to have a low level of activity. Inversely, the higher the BMI the higher the PA level. The possible explanation of this finding is that the $\mathrm{BMI}$ in this study was defined only by the body weight and height but not the body composition. Participants with higher BMI may actually be more muscular than the lower BMI. These muscular participants may also be more engaged in moderate to high physical activity than in low. Another possible explanation may be due to the motivational reason that the participants with higher BMI do more activities to lose their weight and lowering their BMI.

In this study, both female and male participants mostly had low PA levels. In female groups, the dominant PA was low, followed by moderate and high. In male groups, the dominant PA was low, followed by high and moderate. The statistical analysis of PA level between gender in this study showed that female tends to be more inactive than male (OR 2.004, 95\% Cl (1.038-3.8690). Similar findings were also found from research of medical students in Thailand which found that more than $50 \%$ of the participants were physically inactive. Furthermore, the research showed that female were less active than male (OR 0.43; $95 \% \mathrm{Cl}$ 0.25-0.73) (2). Female participants were more inactive than males in our study might be due to some reasons. For examples, limited sports facilities for female, cultural factors and traditional beliefs, religious factors, and TV programs and magazines that are more attractive for female (19). Sports facilities center like the gym around our neighborhood (Semarang) was still dominated by males. That condition, however, will make females feel hesitant to come and create an uncomfortable feeling especially for hijabi. Related to cultural factors and traditional beliefs, some people consider that females are better to stay at home and lessen their involvement in outdoor activities. The religious factor that limits the interaction between males and females might be a concern to limit the involvement in outdoor activities. TV programs and magazines that are more attractive for females made them spend more time sitting and reading at home instead of going outdoor.

It has been shown that the prevalence of prehypertension among our participants was higher than the prevalence of hypertension. This finding was almost similar to that of a previous study that showed the prevalence of prehypertension and hypertension among the young adult population in a rural area of West Java that was $34.2 \%$ and $17.1 \%$, respectively (20). People with prehypertension are considered to develop hypertension in the future (21). However, our study did not show a association between PA level and BP either systolic or diastolic pressure, which is different from that of the study in Malaysia that showed a positive association between PA 
and systolic BP (10). Another study in India among children as the sample also showed a positive association of diastolic BP and moderate activity levels in the male group with elevated blood pressure (22). In West Java, Indonesia, a study among 111 young adults found that there was a association between PA and prehypertension $(\mathrm{OR}=2.6 ; \mathrm{Cl} 95 \%=0.975-6.931 ; \mathrm{p}=0.052)$ but not with hypertension ( $p=0.498$, Fisher test) (20). These different findings might due to different measurements of BP and PA levels.

A significant difference between systolic BP among male and female groups was shown in this study $(p$ value $=0.000$ ). Male was correlated with higher systolic BP than female. This finding was similar to that of a previous study, which showed an association between higher systolic BP and high-intensity exercise compared to low or moderate-intensity especially in male adolescents (6). The possible reasons are that males have more outdoor activities, spend more time on hobbies especially sport or exercise related hobbies, and spend less time studying, thereby increasing the systolic BP (6).

The association between PA level and non-fasting blood glucose level (NFBG) was not seen in this study. Previous study has shown a significant positive asociation between PA level and blood glucose among adult in Malaysia (10) which is consistent with other research reports which showed an association between higher activity level and lower level of blood glucose $(23,24)$. These differences in findings between our study and other studies might due to the characteristic of subjects. The mean age of our participants was 18.45 years old. The age itself is related to blood glucose levels. The ability to regulate blood glucose decrease with age. The secondary influences of body fat and physical fitness explain the reduction in glucose tolerance from young to middle age $(25,26)$. PA level was also associated with age. A study showed that physical activity level decreased in subjects aged more than 52 years old (27). Another study concluded that the medium intensity of physical activity declined in older adults (28). None of the participants had an NFBG level of more than $200 \mathrm{mg} / \mathrm{dL}$ or any history of suspicious symptoms of

\section{REFERENCES}

1. World Health Organization. Global Status Report on Communicable Disease 2014. Geneva, Switzerland; World Health Organization; 2014.

2. Wattanapisit A, Fungthongcharoen K, Saengow U, and Vijitpongjinda S. Physical Activity among Medical Students in Southern Thailand: A Mixed Methods Study. The British Medical Journal. 2016; 6(9): 1-7.

3. World Health Organization. Global Strategy on Diet, Physical Activity, and Health. Geneva, Switzerland; World Health Organization; 2004.

4. World Health Organization. Global Recommendations on Physical Activity for Health, 18-64 Years Old. (Geneva World Heal Organ. Online). http://www.who.int/dietphysicalactivity/physicalactivity-recommendations-18-64years.pdf?ua=1

5. Li J and Siegrist J. Physical Activity and Risk of Cardiovascular Disease-a Meta-Analysis of Prospective Cohort Studies. International Journal of
T2DM. Besides, other confounding factors might contribute to the NFBG level, such as dietary intake. In our study, NFBG levels tended to be low. This might due to the time of the NFBG test that was done around 11.00 am to $01.00 \mathrm{pm}$ after participants completed the module of regular examination before lunch.

In this study, the IPAQ-short form to measure the PA level was used as recommended by previous studies $(6,10)$. The estimation of the PA level method was a subjective measurement and tended to have recall bias and the possibility of the participants to report socially desirable responses (10). Moreover, the IPAQ-short form only investigates participant activity in the past seven days which will not represent the PA level over a long period. Our study does not explore the background reason of the participants in carrying out a particular level of activity. Besides, other contributing factors that may correlate with activity level or BMI in our study were not yet completely elucidated. BMI is one of the indicators for nutritional and health status (19), while PA is one of the factors that improve physical fitness status $(18,29)$. Due to the correlation between PA and BMI, encouraging medical students to have better nutrition and lifestyle changes is very important for their own benefit and health promotion for their patients $(19,30)$.

This study shows that medical students need to be more physically active, particularly females. An approach involving the university's policies that emphasize health promotion to raise physical activity in the university environment should be suggested. Then, we also suggest for the more objective measurement for BP using a more valid tool, exclude other possible factors that might contribute to blood pressure like an anti-hypertensive drug, ingestion of coffee, or excessive exercise.

\section{ACKNOWLEDGEMENT}

The authors would like to thank LPPM UNISSULA for the grant. We also thanked all the medical students who participated in this study. Special thank was dedicated to the Physiology Laboratory, Faculty of Medicine, UNISSULA and all the physiology laboratory assistants.
Environmental Research and Public Health. 2012; 9(2): 391-407.

6. Tsioufis C, Kyvelou S, Tsiachris D, et al. Relation Between Physical Activity and Blood Pressure Levels in Young Greek Adolescents: The Leontio Lyceum Study. European Journal of Public Health. 2011; 21(1): 63-68.

7. Diaz KM and Shimbo D. Physical Activity and the Prevention of Hypertension. Current Hypertension Reports. 2013; 15(6): 659-668.

8. Pinckard K, Baskin KK, and Stanford KI. Effects of Exercise to Improve Cardiovascular Health. Frontiers Cardiovascular Medicine. 2019; 6: 1-12.

9. Tian D and Meng J. Exercise for Prevention and Relief of Cardiovascular Disease: Prognoses, Mechanisms, and Approaches. Oxidative Medicine and Cellular Longevity. 2019; 2019: 1-11.

10. Teh $\mathrm{CH}, \mathrm{Chan} \mathrm{YY}, \mathrm{Lim} \mathrm{KH}$, et al. Association of Physical Activity with Blood Pressure and Blood Glucose among Malaysian Adults: A Population-Based Study. 
BMC Public Health. 2015; 15: 1-7.

11. Qin L, Knol MJ, Corpeleijn E, and Stolk RP. Does Physical Activity Modify the Risk of Obesity for Type 2 Diabetes: A Review of Epidemiological Data. European Journal of Epidemiology. 2010; 25(1): 5-12.

12. Vasques C, Mota M, Correia T, and Lopes V. Prevalence of Overweight/Obesity and Its Association with Sedentary Behavior in Children. Revista Portuguesa de Cardiologia. 2012; 31(12): 783-788.

13. Marlina Y, Huriyati E, and Sunarto Y. Indeks Massa Tubuh dan Aktivitas Fisik dengan Tekanan Darah pada Pelajar SMA. Jurnal Gizi Klinik Indonesia. 2016; 12(4): 160-166.

14. Cheng HL. A Simple, Easy-To-Use Spreadsheet for Automatic Scoring of the International Physical Activity Questionnaire (IPAQ) Short Form. (Online) 2016. https://www.researchgate.net/publication/ $310953872_{\text {_ A }}$ s i m ple_e a s y - to use_spreadsheet_for_automatic_scoring_of_the_I nternational_Physical_Activity_Questionnaire_IPA Q_Short_Form

15. Lee PH, Macfarlane DJ, Lam TH, and Stewart SM. Validity of the International Physical Activity Questionnaire Short Form (IPAQ-SF): A Systematic Review. The International Journal of Behavioral Nutrition and Physical Activity. 2011; 8: 1-11.

16. World Health Organization. Section 4: Guide to Physical Measurements (Step 2). (Online). https://www.who.int/ncds/surveillance/steps/Sect ion 4 Step 2 Physical Measurements.pdf

17. Yousif MM, Kaddam LA, and Humeda HS. Correlation Between Physical Activity, Eating Behavior And Obesity Among Sudanese Medical Students Sudan. BMC Nutrition. 2019; 5(6): 1-8.

18. Al-Asousi $\mathrm{M}$ and El-Sabban F. Physical Activity among Preclinical Medical Students at the University of Malaya, Malaysia. Journal of Nutritional Health \& Food Science. 2016; 4(2): 1-9.

19. Keykhaei F, Shahraki M, Sargolhosseinzadeh E, Shahraki T, and Dashipour A. Correlation of Body Mass Index and Physical Activity Among 7- to 11Year Children at Zahedan, Iran. Food and Nutrition Bulletin 2016; 37(3): 364-374.

20. Widjaja FF, Santoso LA, Barus NRV, Pradana GA, and
Estetika C. Prehypertension and Hypertension among Young Indonesian Adults at a Primary Health Care in a Rural Area. Medical Journal of Indonesia. 2013; 22(1):39-45.

21. Zhang $\mathrm{W}$ and Li N. Prevalence, Risk Factors, and Management of Prehypertension. International Journal of Hypertension. 2011; 2011: 1-6.

22. Durrani AM and Fatima W. Effect of Physical Activity on Blood Pressure Distribution among School Children. Advances in Public Health. 2015; 2015: 1-4.

23. Sakung JM, Sirajuddin S, Zulkifli A, Rahman SA, and Sudargo T. Physical Activity is Associated with Lower Blood Glucose Level in High School Teachers in Palu, Indonesia. International Journal Community Medicine and Public Health. 2018; 5(8): 1-4.

24. Adams OP. The Impact of BriefHigh-Intensity Exercise on Blood Glucose Levels. Diabetes, Metabolic Syndrome and Obesity: Targets and Therapy. 2013; 6: 113-122.

25. Chia CW, Egan JM, and Ferrucci L. Age-Related Changes in Glucose Metabolism, Hyperglycemia, and Cardiovascular Risk. Circulation Research. 2018; 123(7): 886-904.

26. Kalyani RR and Egan JM. Diabetes and Altered Glucose Metabolism with Aging. Endocrinology and Metabolism Clinics of North America. 2013; 42(2): 333-347.

27. Speakman JR and Westerterp KR. Associations between Energy Demands, Physical Activity, and Body Composition in Adult Humans between 18 and $96 Y$ of Age. The American Journal of Clinical Nutrition. 2010; 92(4): 826-834.

28. Takagi D, Nishida Y, and Fujita D. Age-Associated Changes in the Level of Physical Activity in Elderly Adults. Journal of Physical Therapy Science. 2015; 27(12): 3685-3687.

29. Rauner A, Mess F, and Woll A. The Relationship between Physical Activity, Physical Fitness and Overweight in Adolescents: A Systematic Review of Studies Published in or after 2000. BioMed Central Pediatrics. 2013; 13(1): 1-9.

30. Rao CR, Darshan B, Das N, Rajan V, Bhogun M, and Gupta A. Practise of Physical among Future Doctors: A Cross Sectional Analysis. International Journal of Preventive Medicine. 2012; 3(5): 365-369. 